\title{
Pengaruh Kompetensi dan Lingkungan Kerja Terhadap Kinerja Karyawan PT. Bank Rakyat Indonesia Kantor Cabang Makassar
}

\author{
Ismail Hajiali', Mahfudnurnajamuddin², Suriyanti ${ }^{3}$, Aditya Halim Perdana Kusuma Putra4 \\ 1,2,3,4 Fakultas Ekonomi dan Bisnis, Universitas Muslim Indonesia
}

Email Korespondensi: hajiali.ismail2@gmail.com/ismail.ha@umi.ac.id

\begin{abstract}
Abstrak
Penelitian ini bertujuan untuk mengetahui pengaruh kompetensi dan lingkungan kerja terhadap kinerja karyawan PT. Bank Rakyat Indonesia (persero), Tbk Kantor Cabang Makassar. Penelitian ini menggunakan pendekatan deskriptif. Objek penelitiannya adalah karyawan PT. Bank Rakyat Indonesia (persero), Tbk Kantor Cabang Makassar dan proses pengumpulan data dilakukan dengan angket/kuesioner dengan jumlah sampel 30 orang. Adapun metode analisis data yang digunakan adalah analisis deskriptif, uji realibilitas, uji validitas, analisis regresi berganda, uji asumsi klasik dan uji statistik. Hasil penelitian menunjukkan bahwa kompetensi berpengaruh positif dan signifikan terhadap kinerja karyawan dimana berdasarkan nilai koefisien regresi diperoleh nilai positif, dan uji-t memiliki nilai t-hitung sebesar $(6,597)>$ t-tabel $(2,0518)$, dan nilai sig 0,000 < 0,05 dan sedangkan lingkungan kerja berpengaruh positif dan tetapi tidak signifikan terhadap kinerja karyawan karena memiliki t-hitung sebesar $(0,409)<\mathrm{t}$-tabel $(2,0518)$, dan nilai sig $(0,686)>(0,05)$.
\end{abstract}

Kata Kunci: Kompetensi, Lingkungan Kerja, Kinerja Karyawan

\section{Pendahuluan}

Mengingat perkembangan teknologi diera saat ini, pastinya perusahaan atau instansi dituntut harus terus berkembang untuk mempertahankan posisi atau reputasinya dimata masyarakat. Banyak faktor yang dituntut kepada perusahaan untuk lebih mengembangkan perusahaan dan mendapatkan citra baik dimata masyarakat. Salah satu faktor yang sangat mempengaruhi kelangsungan hidup suatu perusahaan yaitu karyawan. Karyawan merupakan titik tolak keberhasilan dalam mencapai tujuan suatu perusahaan. Jika dalam suatu perusahaan memiliki karyawan berpotensi berkembang dan maju maka dipastikan perusahaan tersebut akan terus mendapatkan benefit yang diinginkan untuk dicapai. Karyawan juga memiliki tingkat hasil atau kinerja yang patut dipertimbangkan dan menjadi pembanding antara karyawan satu dengan karyawan yang lainnya karena setiap karyawan memiliki tingkat hasil pekerjaan yang berbeda-beda sesuai dengan kemampuannya. Kinerja karyawan merupakan hal utama yang dilihat perusahaan untuk melakukan penilaian dan evaluasi kerja. Oleh karena itu kinerja karyawan dianggap sebagai bagian terpenting oleh perusahaan, karena hal tersebut bersangkutan langsung dengan hasil kemampuan dan keterampilan semua sumber daya manusia perusahaan yang merupakan otak utama perusahaan untuk membantu pencapaian tujuan utama perusahaan.

Menurut Wibowo, kinerja karyawan adalah tujuan dari hasil kerja yang akan dicapai seseorang dari pekerjaan yang diembannya (C. T. Wibowo, 2015). Menurut Mangkunegara, kinerja karyawan adalah hasil kerja yang akan dicapai oleh seseorang, baik itu secara kualitas ataupun kuantitas dalam melaksanakan pekerjaannya sesuai dengan tanggung jawab yang diberikan kepadanya (Fajrin \& Susilo, 2018). Di dalam perusahaan, tinggi rendahnya tingkat kinerja karyawan dapat disebabkan oleh beberapa faktor. Telah diketahui bahwa penilaian kinerja karyawan merupakan bagian terpenting dalam proses kerja perusahaan maka dari itu karyawan akan memerlukan faktor-faktor, diantaranya faktor kompetensi dan lingkungan kerja. 
Salah satu perusahaan yang dituntut untuk memiliki kinerja yang optimal dan terus mengevaluasi hasil kinerja karyawannya adalah PT. Bank Rakyat Indonesia (persero), Tbk Kantor Cabang Makassar, dimana para karyawan harus professional dalam melaksanakan pekerjaannya dan juga bertanggung jawab. Dengan demikian akan memberikan pelayanan yang memuaskan kepada nasabah. Namun pada kenyataannya berdasarkan hasil pengamatan di PT. Bank Rakyat Indonesia (persero), Tbk Kantor Cabang Makassar, dimana kinerja karyawan berada pada kondisi belum optimal. Hal tersebut dapat dilihat dari berbagai kondisi yang terjadi antara lain, ada beberapa karyawan yang ditugaskan untuk suatu hal ternyata tidak menguasai bidangnya dan karyawan yang lain yang bukan menempati posisinya dapat menyelesaikan tugas tersebut. Selain itu ada beberapa karyawan tidak memanfaatkan waktu luang pada jam kerja, misalnya ngobrol, makan, istirahat sebelum waktunya, yang keseluruhan terjadi pada saat jam kerja. Masih banyak karyawan yang membuat kesalahan ketika bekerja sehingga kualitas kerjanya tidak sesuai dengan standar kerja yang telah ditetapkan. Selain itu masih banyak juga karyawan yang kuantitas pekerjaannya belum sesuai dengan target yang telah ditetapkan.

Kompetensi adalah sesuatu yang berhubungan dengan apa yang bisa dan tidak bisa dilakukan, berhubungan dengan kesempatan, mampu atau tidaknya meraih kesempatan tersebut. Menurut Hutapea dan Thoha, Kompetensi adalah kemampuan dan kemauan dalam melakukan sebuah pekerjaan dengan baik, sehingga akan menghasilkan kinerja yang efektif dan efisien guna mencapai tujuan dari perusahaan (Hutapea \& Nurianna Thoha, 2008). Lingkungan kerja merupakan seluruh alat pekerjaan dan bahan yang digunakan, maupun lingkungan sekitar dimana seseorang bekerja, dan metode kerja juga pengaturan kerja, baik metode secara individual maupun kelompok. Menurut Nasution lingkungan kerja merupakan segala kondisi dimana karyawan bekerja dapat mempengaruhi kondisinya baik secara fisik ataupun psikologi mereka, baik langsung maupun tidak langsung sehingga menghasilkan kinerja yang tinggi (Fitri \& Nasution, 2016). Hal ini menunjukkan bahwa apapun yang dilakukan karyawan ketika bekerja selalu berhubungan dengan lingkungan kerja, dimulai dari metode kerja hingga alat pekerjaan yang digunakan. Kompetensi dan lingkungan kerja yang baik dapat juga menunjang keberhasilan suatu perusahaan dalam mencapai tujuannya. Sebab melalui adanya dua faktor tersebut akan menciptakan tingkat kinerja karyawan yang tinggi sehingga menunjang keberhasilan perusahaan. Di bagian pelayanan PT. Bank Rakyat Indonesia (persero), Tbk Kantor Cabang Makassar yang menjadi masalah bagi instansi adalah kinerja karyawan. Banyak karyawan yang sering merasakan ketidaknyamanan dalam lingkungan kerjanya, contohnya sirkulasi udara yang sering terhambat sehingga terasa panas di ruangan, kondisi ruangan yang jika sedang dalam keadaan ramai sering terjadi desakan sehingga mengganggu mobilitas dalam bekerja, bau yang tidak sedap sering berada dalam ruangan yang dapat menggangu dalam proses bekerja, dan suara bising kadang menggangu karyawan dalam bekerja. Hal inilah dapat menyebabkan kinerja karyawan menurun disebabkan karna masalah seperti itu. Kompetensi sebagai karakteristik yang mendasari seseorang dan berkaitan dengan efektivitas kinerja individu dalam pekerjaanya. Terlepas dari faktor yang melatar belakangi terjadinya penurunan dari suatu kinerja karyawan selain kompetensi, lingkungan kerja juga penting dalam meningkatkan kinerja karyawan. Semakin lingkungan kerjanya nyaman dan aman bagi karyawan maka akan semakin betah dan ingin berlama-lama di tempat kerjanya yang dimilikinya. Oleh sebab itu berdasarkan latar belakang yang telah diuraikan, maka dapat dikemukakan masalah pokok dalam penelitian ini: 1). Apakah kompetensi berpengaruh terhadap kinerja karyawan PT. Bank Rakyat Indonesia (persero), Tbk Kantor Cabang Makassar. 2) Apakah lingkungan kerja berpengaruh terhadap kinerja karyawan PT. Bank Rakyat Indonesia (persero), Tbk Kantor Cabang Makassar

\section{Tinjauan Pustaka}

\subsection{Teori Organisasi}

Teori Organisasi yaitu teori yang menyatakan bahwa setiap individu pasti memiliki keterbatasan dari berbagai hal atau unsur yang menjadikannya tidak akan mampu mewujudkan apa yang akan dicapainya dengan sendirinya. Dalam hal inilah maka setiap individu membutuhkan orang lain untuk memenuhi segala yang akan dicapainya dengan menjalin sebuah kerja sama. Oleh karenanya, teori organisasi berpandangan bahwa manusia merupakan makhluk sosial yang sewajibnya bermasyarakat guna mencapai tujuan atau sasarannya secara bersama-sama. Menurut Hodge dan Anthony, teori organisasi adalah kumpulan ide, pedoman, maupun jawaban sementara yang digunakan untuk menjelaskan bagian-bagian dalam organisasi yang sesuai dengan fungsinya masing-masing. Oleh 
karena itu teori organisasi membuat kita lebih memahami secara mendalam apa itu organisasi dan hubungannya dengan lingkungannya (Hodge et al., 1988). Menurut jones, teori organisasi adalah sebuah studi bagaimana organisasi menjalankan fungsinya serta pengaruh dari lingkungan sekitar organisasi. Jadi teori ini menjelaskan tentang cara dalam menganalisis kegiatan organisasi, dan bagaimana organisasi harus belajar serta mampu menyesuaikan diri dengan perubahan lingkungan organisasi (Jones, 2001). Griffin, organisasi merupakan sebuah tanggung jawab yang diberikan ke dalam sistem kerja yang harus dilaksanakan agar berlangsung sebuah kerja sama guna menghasilkan tujuan yang ingin dicapai (Rafferty \& Griffin, 2009). Menurut Sutarto organisasi adalah satu kesatuan yang saling berpengaruh antar individu di dalam sebuah organisasi dengan bekerja bersama untuk tujuan yang diinginkan (Wijono, 2010). Menurut Lubis dah Husein, teori organisasi itu adalah sebuah ilmu pengetahuan yang menyangkut tentang cara bekerja sama, antara dua orang atau lebih secara menyeluruh guna untuk mencapai sasaran yang telah direncanakan sebelumnya (Ningsih et al., 2018). Stoner mengatakan bahwa organisasi adalah suatu sistem yang terhubung dibawah pengarahan atasan untuk mencapai tujuan yang telah direncanakan (Wahyuadianto, 2010). Cyrill Soffer menjelaskan bahwa organisasi adalah kumpulan orang-orang yang memiliki tanggung jawab masing-masing dan mampu menguraikan pekerjaannya dalam suatu sistem kerja. Barnard memiliki pandangan bahwa organisasi adalah terdiri dari dua orang maupun lebih didalam suatu pola kegiatan yang didasari dengan kerja sama secara koperatif (Scott, 1995). Menurut Kast \& Rosenzweig organisasi adalah bagian dari teknik, susunan, psikologi dan sosial serta sistem manajerial dimana kumpulan orang berorientasi pada tujuan dari lingkungan yang lebih luas (Kast \& Rosenzweig, 1972).

Indikator organisasi menurut The Liang Gie salah satunya adalah struktur Organisasi yaitu bagan yang merealisasikan sistem tetap dari hubungan di bidang kerja, maupun per individu menunjukkan peranannya masing-masing dalam hal kerjasama (Paliema et al., 2016). Menurut Numberi Struktur organisasi adalah hal yang sangat penting yang akan menjelaskan bagaimana, tugas, kedudukan dan fungsi disediakan di dalam organisasi (Paliema et al., 2016). Robbins dan Coulter Struktur organisasi dapat diartikan sebagai konsep kerja formal yang dimiliki oleh organisasi yang dengan sistem kerja itu tugas individu dibagi, dikelompokkan, dan dikoordinasikan (Ashari, 2013). Kedua, indikator organisasi adalah perilaku organisasi dimana menurut Fred Luthan, Perilaku organisasi didefinisikan sebagai Studi dan bagian dari pemahaman, bagaimana individu ataupun kelompok bergerak dalam organisasi (Luthan, 2006). Menurut Griffin Perilaku organisasi adalah tolak ukur sejauh mana individu memahami dan terikat pada organisasinya. individu yang memiliki dedikasi yang tinggi kemungkinan melihat dirinya sebagai anggota penting dalam suatu organisasi (Moorhead \& Griffin, 2013). Menurut James L. Gibson perilaku organisasi merupakan sebuah studi yang menjelaskan bagaimana sikap dan karakter individu di dalam suatu lingkungan organisasi (Gibson et al., 1996). Indikator ketiga adalah perubahan organisasi. Menurut Desplaces dalam perubahan organisasi seringkali membawa pengaruh yang tidak menguntungkan. Tetapi perubahan tetap penting dilakukan untuk mengubah aspek yang tidak sesuai dengan kondisi sebelumnya, agar mencapai tujuan organisasi secara efektif dan efisien (Desplaces, 2005). Menurut Robbins Perubahan organisasi yaitu pada hakikatnya bertujuan untuk peningkatan keefektifan organisasi dengan maksud untuk mengupayakan kembalinya kemampuan organisasi untuk menyesuaikan dengan perubahan lingkungan serta setiap perubahan perilaku anggota organisasi (Robbins \& Galperin, 2010). Perkembangan mempunyai arti munculnya sifat-sifat yang baru, yang berbeda dari sebelumnya. Dapat diartikan bahwa perkembangan merupakan adanya perubahan sifat dari individu menuju yang lebih baik dibandingkan sifat sebelumnya (Kasiram \& Raj, 2011). Menurut Tyagi bahwa pengembangan organisasi sebagai usaha yang terencana, teratur, terukur, dan lebih bersifat kerjasama antara prinsip pengetahuan mengenai perilaku dan teori organisasi digabungkan dan diaplikasikan guna meningkatkan mutu kehidupan organisasi yang terarah pada peningkatan kesehatan dan kehidupan organisasi (Tyagi et al., 2015).

\subsection{Social Contagion Theory (Teori Penularan Sosial)}

Merupakan jenis pengaruh sosial yang artinya seseorang yang bermasyarakat akan cenderung meniru perilaku orang lain atau bisa jadi meniru perilaku atau kebiasaan yang bersifat spontan orang lain yang berada disekitarnya/ lingkungannya (Berger, 2008). Burt mengatakan teori penularan (contagion) yaitu sebagai jalan untuk menularkan sikap dan perilaku oleh jaringan komunikasi. Dalam teori ini Jaringan komunikasi memiliki fungsi sebagai pandangan yang menunjukkan orang-orang, kelompok, dan organisasi sebagai informasi mengenai sikap dan perilaku individu yang lain (Burt, 
1987). Menurut Burkhardt, penularan dapat dibedakan menjadi penularan oleh kohesi yaitu mengacu pada pengaruh setiap individu yang berkomunikasi langsung. Pandangan orang-orang ini dari sistem baru yang secara langsung dipengaruhi oleh orang-orang yang memiliki komunikasi langsung. Sedangkan penularan oleh kesetaraan struktural berfokus pada pengaruh individu yang memiliki sistem komunikasi yang sama (Hapsari, 2016). Menurut Locher, Teori Penularan (Contagion Theory) memeriksa setiap peristiwa sosial dan keadaan yang dapat menimbulkan perilaku yang ada di kerumunan (Locher, 2002). Penularan Sosial (social contagion) adalah proses penyebaran suasana hati, perasaan atau perilaku yang irasional, secara relatif dan tanpa disadari berlangsung cepat. Penularan ini dapat dianggap suatu gejala yang membuat individu tidak sadar, sudah tidak memikirkan kepentingannya melainkan kepentingan bersama, dikarenakan telah tertular oleh perasaan dan perilaku yang disekitarnya. Gagasan umum dari penularan sosial adalah bahwa setiap individuindividu akan terpengaruh atau terinfeksi oleh pikiran, emosi, perilaku, dan ide jika berada dalam suatu kerumunan dan sebaliknya (Paradizsa et al., 2019). Menurut Le Bon, ciri yang menonjol pada masyarakat ditekan pada hal yang paling rendah saat mereka berada disituasi kerumunan. Penularan pada kerumunan ini bisa menghilangkan semua perbedaan kultural dan pendidikan diantara anggotaanggota kerumunan, mereka direduksi hingga ke titik persetujuan yang paling rendah, karena itu kepribadian biasanya direduksi di dalam kerumunan. Akibatnya seseorang yang berada dalam kerumunan cenderung berperilaku merusak. Mereka dapat berperilaku yang tidak masuk akal berdasarkan insting mereka. Akibat dari teori penularan ini adalah berkembangnya suggesti dimana kerumunan bisa paling cepat menyebar pada khayalan yang paling tidak masuk akal. Dengan daya sugesti sebagai pemimpin dalam kerumunan ini dapat memaksakan kehendaknya (Paradizsa et al., 2019). Menurut Erickson, Teori penularan mencari hubungan antara anggota organisasi dan kelompok mereka. Pengetahuan, psikologi dan karakter anggota organisasi terkait dengan informasi, sikap, dan perilaku dengan yang lainnya dalam jaringan yang terhubung dengan mereka. Faktor seperti jumlah, sejauh mana jaringan mereka terhubung, kekuatan, dan perbedaan dapat membentuk sejauh mana individu mempengaruhi yang lainnya dalam jaringan mereka (Paradizsa et al., 2019).

Adapun Indikator Penularan Sosial menurut Locher proses psikologis untuk menjadi bagian dari suatu kerumunan (crowd) meliputi tiga aspek yaitu : Individu merasa berani dan tidak mengetahui siapa dirinya; Dalam hal ini orang - orang yang terlibat dalam perilaku, dimana secara normal ada tekanan rasa takut dan kesadaran diri mereka dikontrol. Sementara secara personal, dapat menghilangkan kekhawatiran dan akibat dari perilaku yang terjadi. Atas dasar inilah menyebabkan timbulnya keberanian dan perasaan memiliki kekuatan bersama. Biasanya mereka yang tidak pernah melanggar dan patuh terhadap aturan dan hukum akan melanggarnya dan tidak takut akan diberi hukuman atau ditangkap. Terjadinya peniruan Dalam kondisi tidak sadar, setiap pandangan maupun tindakan akan berpindah secara meluas kepada individu yang lain. Dimana kepentingan pribadi dikorbankan menjadi kepentingan kelompok. Kelompok masuk kedalam sugestibilitas; Setiap individu tidak menyadari sikap mereka sendiri jika berada di kondisi ini, perhatian mereka dialihkan ke objek / kejadian yang sama. individu yang tidak setuju dengan hal-hal dari kelompok tidak akan mampu menolaknya karna merasa kalah banyak, bahkan jika mencoba menolak mereka akan diabaikan oleh orang-orang pada umumnya, kecuali mereka dapat memberikan hal yang menarik dan memuaskan. Anggota suatu kelompok / kerumunan biasanya melakukan tindakan tanpa berfikir panjang dan mungkin ingin merasakan perilaku yang hebat, dimana dalam kondisi normal biasanya mereka takut melakukannya, kemudian bahwa dalam setiap perilaku dalam kerumunan / kelompok selalu bersifat anarkis/merusak (Locher, 2002).

\subsection{Kompetensi}

Munro dan Andrews menegaskan bahwa mengingat di era sekarang yang hiper kompetitif yang berbasis ilmu pengetahuan, kompetensi sangat dibutuhkan karena merupakan aset yang tidak ternilai bagi perusahaan sebagai alat untuk membangun dan meraih keunggulan bersaing dalam jangka panjang untuk perusahaan. Kompetensi termasuk didalamnya adalah pengetahuan, keterampilan, dan kemampuan yang berhubungan dengan Pekerjaan (Budhiningtias Winanti, 2011). Rivai dan Fawzi, Kompetensi adalah suatu pekerjaan dalam bentuk dan tingkatan perilaku yang berbeda, setiap individu mempunyai kemampuan sesuai apa yang dibutuhkan. Oleh karena itu kompetensi setiap individu mempengaruhi proses dari hasil pekerjaan (Hendriani et al., 2013). Menurut Hutapea dan Thoha, Kompetensi adalah kemampuan dan kemauan dalam melakukan sebuah pekerjaan dengan baik, 
sehingga akan menghasilkan kinerja yang efektif dan efisien guna mencapai tujuan dari perusahaan (Hutapea \& Nurianna Thoha, 2008). Boulter, Dalziel, dan Hill mengemukakan kompetensi adalah suatu karakteristik dasar dari seseorang yang kemampuannya dapat memberikan kinerja yang unggul dalam suatu instansi (Sutrisno, 2008). Menurut Wibowo Kompetensi adalah suatu kemampuan untuk melakukan suatu pekerjaan yang dilandasi oleh keterampilan dan pengetahuan dan didukung oleh sikap kerja yaitu pengalaman ataupun pembelajaran yang dituntut oleh pekerjaan tersebut. Wibowo juga menyatakan bahwa kompetensi merupakan kemampuan seseorang dalam kerja yang berlandaskan keterampilan dan pengetahuan dengan menyertakan sikap individu dalam bekerja. Hal yang juga tidak kalah pentingnya untuk menunjang kompetensi ialah peran serta pengalaman dan pembelajaran dalam pelaksanaan berbagai tugasnya secara baik dan professional (N. Wibowo, 2016).

Indikator Kompetensi menurut Sutrisno menekankan beberapa indikator dari kompetensi, yaitu: Pengetahuan (Knowledge); Kesadaran dalam bidang kognitif (pengetahuan). Misalnya Seorang Pegawai mengetahui cara menemukan hal-hal yang diperlukan untuk belajar dan bagaimana melakukan pembelajaran yang baik sesuai apa yang dibutuhkan oleh suatu perusahaan. Pengetahuan merupakan suatu informasi yang dimiliki seseorang pada bidang yang khusus ataupun yang diperoleh dari manusia itu sendiri melalui sesuatu yang pernah terjadi didalam dirinya. Pemahaman (Understanding); Dalam hal kognitif (pengetahuan), dan afektif (sikap / nilai), yang dimiliki oleh individu. Maka, untuk memberikan pemahaman dalam hal ini dapat diberikan contoh dalam suatu organisasi atau perusahaan, misalnya dalam melaksanakan pembelajaran karyawan harus mempunyai pemahaman yang baik tentang masalah maupun kondisi kerja secara baik dan benar. Nilai (Value); Standar perilaku yang telah menyatu dalam diri seseorang yang diyakini secara psikologis. Misalnya, standar perilaku para pegawai yaitu kejujuran, terbuka dalam segala hal dalam melaksanakan tanggung jawabnya dalam suatu organisasi atau perusahaan. Kemampuan (Skill); Sesuatu yang telah dimiliki oleh seseorang untuk melakukan tanggung jawab atau pekerjaan yang dibebankan pada pegawai oleh suatu organisasi atau perusahaan. Misalnya, standar perilaku para pegawai dalam memilih cara kerja yang dianggap lebih mudah dan cepat. Sikap (Attitude); Perasaan seseorang (baik perasaan yang bersifat positif ataupun negatif) ataupun reaksi terhadap suatu dorongan yang datang dari luar. Misalnya, perasaan saat mendapatkan insentif atau mendapatkan kenaikan gaji. Minat (Interest); Kebiasaan seseorang untuk melakukan suatu perbuatan atau pekerjaan tertentu, Misalnya melakukan suatu aktivitas kerja yang didasarkan karna adanya keinginan ataupun kepentingan terhadap sesuatu (Basori et al., 2017).

\subsection{Lingkungan Kerja}

Lingkungan kerja merupakan tempat dimana para pegawai melakukan aktivitas pekerjaan. Lingkungan kerja bisa membawa dampak positif apabila menciptakan lingkungan yang kondusif. Sebaliknya, bisa membawa dampak negatif apabila lingkungan kerja yang kurang kondusif akan mempengaruhi karyawan dalam bekerja serta dapat juga mempengaruhi hasil kerja dan jangka panjang pekerjaan karyawan. Menurut Alex S. Niti Semito, lingkungan kerja adalah segala sesuatu yang ada disekitar tempat kerja yang dapat mempengaruhi karyawan dalam bekerja, baik dampak positif maupun negatif yang artinya lingkungan kerja dapat berupa sumber informasi ataupun tempat melakukan aktifitas, maka kondisi kerja yang nyaman harus dicapai agar karyawan dapat merasa betah dan nyaman untuk menunjang pekerjaan maupun kelangsungan kerja karyawan (Sukmawati, 2007). Indikator Lingkungan Kerja oleh Nitisemito yaitu sebagai berikut: Suasana Kerja, Hubungan Dengan Rekan Kerja dan tersedianya fasilitas kerja

\section{Metode Penelitian}

Lokasi dan waktu penelitian ini dilakukan di Kab. Sidenreng Rappang tepatnya di PT. Bank Rakyat Indonesia (persero), Tbk Cabang kota Makassar dan diselenggarakan pada bulan Januari sampai pada bulan Februari 2021. Populasi dalam penelitian ini adalah jumlah seluruh karyawan PT. Bank Rakyat Indonesia Kota Makassar sebanyak 30 karyawan. Teknik pengumpulan data menggunakan kuesioner yang terdiri dari beberapa pertanyaan yang diukur dengan skala likert 1-5 (sangat tidak setuju - sangat setuju) (Lihat Tabel. 1). Selanjutnya teknik analisis data menggunakan regresi linear berganda dengan beberapa kriteria pengujian (e.g., uji validitas, normalitas, reliabilitas dan uji hipotesis). 
Tabel 1. Pengukuran Variabel

\begin{tabular}{|c|l|l|}
\hline No & \multicolumn{1}{|c|}{ Variabel } & \multicolumn{1}{c|}{ Indikator } \\
\hline $\mathbf{1 .}$ & Kompetensi $(\mathrm{X} 1)$ & 1.Pengetahuan \\
& & 2.Keterampilan \\
& & 3.Sikap \\
\hline $\mathbf{2 .}$ & Lingkungan Kerja $(\mathrm{X} 2)$ & 1.Kondisi kerja \\
& & 2.Fasilitas kerja \\
\hline & & 3.Hubungan kerja dengan rekan kerja \\
& & 4.Hubungan kerja dengan atasan \\
\hline $\mathbf{3 .}$ & Kinerja Karyawan & 1.Kuantitas hasil kerja \\
& & 2.Kualitas hasil kerja, \\
\hline
\end{tabular}

\section{Hasil Penelitian dan Pembahasan}

4.1. Karakteristik Responden

Responden dalam penelitian ini merupakan karyawan PT. Bank Rakyat Indonesia (persero), Tbk. Kantor Cabang Makassar Responden dalam penelitian ini berjumlah 30 orang. Adapun karakteristik responden yang dimasukkan dalam penelitian ini adalah pekerjaan, usia, jenis kelamin, pendidikan terakhir. Berikut hasil analisa karakteristik responden disajikan pada tabel 2:

Tabel 2 . Karakteristik Responden

\begin{tabular}{|l|c|c|}
\hline \multicolumn{1}{|c|}{ Karakteristik Responden } & Frekuensi & Persentase \\
\hline Usia & & \\
$<30$ Tahun & 11 & $36,7 \%$ \\
$30-40$ & 17 & $56,7 \%$ \\
$40-50$ & 2 & $6,6 \%$ \\
Total & $\mathbf{3 0}$ & $\mathbf{1 0 0} \%$ \\
\hline Jenis Kelamin & & \\
Laki-Laki & 10 & $33,3 \%$ \\
Perempuan & 20 & $66,7 \%$ \\
Total & $\mathbf{3 0}$ & $\mathbf{1 0 0} \%$ \\
\hline Pendidikan Terakhir & & \\
SMA/SMK & 2 & $6,7 \%$ \\
S1 & 28 & $93,3 \%$ \\
Total & $\mathbf{3 0}$ & $\mathbf{1 0 0} \%$ \\
\hline Posisi & & \\
Staff & 14 & $46,7 \%$ \\
Teller & 4 & $13,4 \%$ \\
SPO & 1 & $3,3 \%$ \\
PAB & 5 & $16,7 \%$ \\
CS (Custumer service) & 3 & $10 \%$ \\
BFA & 1 & $3,3 \%$ \\
SP Dana dan Jasa & 1 & $3,3 \%$ \\
Wiraswasta & 1 & $3,3 \%$ \\
Total & $\mathbf{3 0}$ & $\mathbf{1 0 0} \%$ \\
\hline
\end{tabular}


Berdasarkan tabel 2 dapat diketahui bahwa berdasarkan usia, responden yang berusia $<30$ tahun sebanyak 11 orang atau $36,7 \%$ dari jumlah responden, Kemudian responden usia $30-40$ tahun sebanyak 17 orang atau sebesar $56,7 \%$ dan responden usia $40-50$ tahun sebanyak 2 orang atau sebesar $6,6 \%$ dari jumlah sampel. Berdasarkan jenis kelamin dapat diketahui bahwa responden dengan jenis kelamin perempuan lebih mendominasi sebanyak 20 orang atau sebanyak $66,7 \%$ dan responden laki-laki sebanyak 10 orang atau sebesar $33,3 \%$ dari total keseluruhan. Berdasarkan data yang ditunjukkan oleh tabel diatas dapat diketahui bahwa berdasarkan pendidikan terakhir, responden yang memiliki pendidikan terakhir SMA sebanyak 2 orang atau sebesar 6,7\%, kemudian responden yang memiliki pendidikan terakhir S1 sebanyak 28 orang atau sebesar 93,3\% dari total keseluruhan responden. Berdasarkan data yang telah didapatkan dilapangan bahwa, jumlah keseluruhan responden 30 orang dengan pertanyaan sebanyak 22 item yang terdiri dari 3 variabel. Untuk variabel kompetensi terdiri dari 7 instrumen penelitian yaitu X1.1 dengan nilai rata-rata 4,30, X1.2 dengan nilai rata-rata 4,30, kemudian X1.3 dengan nilai rata-rata 4,40, X1.4 dengan nilai rata-rata 4,47, X1.5 dengan nilai rata-rata 4,37, X1.6 dengan nilai rata-rata 4,37 dan X1.7 dengan hasil rata-rata sebesar 4,43. Tanggapan responden pada variabel lingkungan kerja $(\mathrm{X} 2)$ juga terdiri dari 7 instrumen penelitian yaitu X2.1 dengan nilai ratarata 4,47, X2.2 dengan nilai rata-rata 4,50, X2.3 dengan nilai rata-rata 4,40, X2.4 dengan nilai rata-rata 4,33, kemudian X2.5 dengan nilai rata-rata 4,33, X2.6 dengan nilai rata- rata 4,30, X2.7 dengan nilai ratarata 4,33. Untuk variabel kinerja karyawan $(Y)$ terdapat 8 instrumen yaitu $Y 1$ dengan nilai rata-rata 4,47, Y2 dengan nilai rata-rata 4,47, Y3 dengan nilai rata-rata 4,37, Y4 dengan nilai rata-rata 4,33, Y5 dengan nilai rata-rata 4,40, kemudian $\mathrm{Y} 6$ dengan nilai rata-rata 4,37, Y7 dengan nilai rata-rata 4,37 dan Y8 dengan nilai rata-rata 4,43 .

\subsection{Pengujian Instrumen}

Uji Validitas digunakan untuk menguji sejauh mana kevalitan atau kebenaran suatu instrumen sebagai alat ukur variabel penelitian. Pengujian tingkat validitas dalam instrumen penelitian ini dilakukan dengan teknik korelasi, yaitu membandingkan r-hitung dengan r-tabel. Jika r-hitung lebih besar dari r-tabel (r-hitung > r-tabel) maka data dianggap valid. Hasil dari uji validitas dapat dilihat dari tabel 3 berikut ini:

Tabel 3. Uji Validitas

\begin{tabular}{|c|c|c|c|c|c|}
\hline Variabel & & r-Hitung & r-Tabel & Sig. & Keterangan \\
\hline \multirow{7}{*}{$\begin{array}{l}\text { Kompetensi } \\
\quad\left(\mathrm{X}_{1}\right)\end{array}$} & $X_{1.1}$ & 0,815 & \multirow{22}{*}{0,3610} & 0,000 & Valid \\
\hline & $X_{1.2}$ & 0,760 & & 0,000 & Valid \\
\hline & $X_{1.3}$ & 0,791 & & 0,000 & Valid \\
\hline & $\mathrm{X}_{1.4}$ & 0,821 & & 0,000 & Valid \\
\hline & $\mathrm{X}_{1.5}$ & 0,742 & & 0,000 & Valid \\
\hline & $X_{1} .6$ & 0,689 & & 0,000 & Valid \\
\hline & $X_{1.7}$ & 0,818 & & 0,000 & Valid \\
\hline \multirow{7}{*}{$\begin{array}{c}\text { Lingkungan Kerja } \\
\qquad\left(\mathrm{X}_{2}\right)\end{array}$} & $X_{2} .1$ & 0,830 & & 0,000 & Valid \\
\hline & $X_{2} .2$ & 0,878 & & 0,000 & Valid \\
\hline & $\mathrm{X}_{2.3}$ & 0,832 & & 0,000 & Valid \\
\hline & $\mathrm{X}_{2.4}$ & 0,883 & & 0,000 & Valid \\
\hline & $\mathrm{X}_{2.5}$ & 0,916 & & 0,000 & Valid \\
\hline & $X_{2.6}$ & 0,937 & & 0,000 & Valid \\
\hline & $\mathrm{X}_{2.7}$ & 0,848 & & 0,000 & Valid \\
\hline \multirow{8}{*}{$\begin{array}{c}\text { Kinerja Karyawan } \\
(\mathrm{Y})\end{array}$} & $\mathrm{Y}_{1}$ & 0,929 & & 0,000 & Valid \\
\hline & $Y_{2}$ & 0,929 & & 0,000 & Valid \\
\hline & $Y_{3}$ & 0,878 & & 0,000 & Valid \\
\hline & $Y_{4}$ & 0,901 & & 0,000 & Valid \\
\hline & $Y_{5}$ & 0,827 & & 0,000 & Valid \\
\hline & $Y_{6}$ & 0,935 & & 0,000 & Valid \\
\hline & $Y_{7}$ & 0,935 & & 0,000 & Valid \\
\hline & $Y_{8}$ & 0,958 & & 0,000 & Valid \\
\hline
\end{tabular}


Berdasarkan hasil uji validitas diatas dapat diketahui bahwa nilai r-hitung lebih besar dari nilai rtabel dimana nilai $r$ tabel untuk sampel sebanyak 30 orang responden dengan tingkat signifikansi 5\% $(0,05)$ adalah sebesar 0,3610 dan nilai signifikan $<0,05$ sehingga dapat disimpulkan bahwa semua indikator pengukuran dalam kuesioner penelitian ini dinyatakan valid. Uji realibilitas dilakukan untuk mengetahui tingkat kepercayaan atau kehandalan hasil suatu pengukuran walaupun pengukuran tersebut dilakukan secara berulang. metode pengambilan keputusan pada uji realibilitasya itu suatu variabel dikatakan reliable jika nilai cronbach Alpha > 0,60 maka kusioner dinyatakan reliabel. Hasil uji reliabel dapat dilihat pada tabel 4 :

\begin{tabular}{|c|c|c|}
\hline Variabel & Cronbach's Alpha & Keterangan \\
\hline Kompetensi (X1) & 0,890 & Reliabel \\
\hline LingkunganKerja (X2) & 0,948 & Reliabel \\
\hline KinerjaKaryawan $(\mathrm{Y})$ & 0,970 & Reliabel \\
\hline
\end{tabular}

Berdasarkan hasil uji realibilitas pada tabel 6 diatas dapat diketahui bahwa nilai cronbach' Alpha pada variabel Kompetensi (X1) sebesar 0,890, Lingkungan Kerja (X2) sebesar 0,948, Kinerja Karyawan (Y) sebesar 0,970, semua nilai cronbach' alpha pada masing-masing variabel tersebut sudah lebih besar dari 0,60 sehingga dapat disimpulkan bahwa data kuesioner yang digunakan dalam penelitian sudah reliabel. Uji Normalitas merupakan bagian dari uji asumsi klasik yang bertujuan untuk mengetahui apakah nilai residual berdistribusi normal atau tidak. Model regresi yang baik adalah memiliki nilai residual yang berdistribusi normal. Dasar pengambilan keputusan yaitu jika nilai signifikasi $>0,05$ maka nilai residual berdistribusi normal. Hasil dari uji normalitas dapat dilihat pada tabel 7 berikut ini:

Tabel 5. Uji Normalitas

\begin{tabular}{|l|l|r|}
\hline \multicolumn{2}{|c|}{ One-Sample Kolmogorov-Smirnov Test } & \multicolumn{1}{|c|}{ Unstandardized Residual } \\
\hline \multicolumn{2}{|c|}{} & 30 \\
\hline \multirow{2}{*}{ Normal Parameters } & Mean & $0 \mathrm{E}-7$ \\
\hline \multirow{3}{*}{ Most Extreme Differences } & Std. Deviation & 1.46956406 \\
\hline & Absolute & .163 \\
\cline { 2 - 3 } & Positive & .163 \\
\cline { 2 - 3 } & Negative & -.071 \\
\hline Kolmogorov-Smirnov Z & .891 \\
\hline Asymp. Sig. (2-tailed) & .405 \\
\hline a. Test distribution is Normal. & \\
\hline b. Calculated from data. & & \\
\hline
\end{tabular}

Berdasarkan data hasil uji normalitas Kolmogorov-Smirnov pada tabel 7 diatas dapat diketahui bahwa nilai signifikasi yang diperoleh sebesar 0,405 > 0,05 sehingga dapat disimpulkan bahwa distribusi data pada penelitian ini normal, sehingga data tersebut dapat dilanjutkan pada tahap pengujian selanjutnya. Uji Multikolineritas bertujuan untuk mengetahui apakah terdapat korelasi Antara variabel independen atau tidak. Dalam penelitian ini teknik untuk mencari ada tidaknya multikolineritas didalam model regresi dapat dilihat dari nilai tolerance dan variance inflation factor (VIF), nilai tolerance harus lebih besar dari 0,1 dan nilai VIF kurang dari 10. Hasil dari uji multikolineritas dapat dilihat pada tabel 6 berikut ini:

Tabel 6. Uji Multikolinearitas

\begin{tabular}{|c|c|c|c|}
\hline \multirow{2}{*}{ Variabel } & \multicolumn{2}{|c|}{ Collinearity Statistics } & \multirow{2}{*}{ Keterangan } \\
\cline { 2 - 3 } & Tolerance & VIF & \multirow{2}{*}{ Tidak TerjadiMultikolinieritas } \\
\hline Kompetensi $(\mathrm{X} 1)$ & 0,340 & 2,943 & TidakTerjadiMultikolinieritas \\
\hline LingkunganKerja $(\mathrm{X} 2)$ & 0,340 & 2,943 & . \\
\hline
\end{tabular}


Berdasarkan data hasil uji multikoliniearitas yang ditunjukkan oleh tabel 8 diatas dapat diketahui bahwa tidak terjadi Multikolinieritas, berdasarkan tabel diatas diketahui variabel Kompetensi (X1) memiliki nilai tolerance sebesar 0,340 dimana lebih besar dari 0,1 dan nilai VIF 2,943 < 10, kemudian Lingkungan Kerja (X2) memiliki nilai tolerance 0,340 dimana lebih besar dari 0,1 dan nilai VIF sebesar $2,943<10$ sehingga dapat disimpulkan bahwa tidak ada multikolinearitas diantara variabel bebas tersebut sehingga data tersebut dapat dilanjutkan pada tahap pengujian selanjutnya.

\subsection{Analisis Regresi Linear Berganda}

Analisis regresi linear berganda bertujuan untuk menguji hubungan pengaruh Antara satu variabel terhadap variabel lain. Hasil dari analisis regresi linear berganda dapat dilihat pada Tabel 7 berikut ini :

Tabel 7. Regresi Linear Berganda

\begin{tabular}{|c|c|c|c|c|c|c|}
\hline \multicolumn{7}{|c|}{ Coefficients ${ }^{a}$} \\
\hline & \multirow{2}{*}{ Model } & \multicolumn{2}{|c|}{$\begin{array}{l}\text { Unstandardized } \\
\text { Coefficients }\end{array}$} & \multirow{2}{*}{$\begin{array}{c}\begin{array}{c}\text { Standardized } \\
\text { Coefficients }\end{array} \\
\text { Beta }\end{array}$} & \multirow{2}{*}{$\mathrm{T}$} & \multirow{2}{*}{ Sig. } \\
\hline & & B & Std. Error & & & \\
\hline \multirow{3}{*}{1} & (Constant) & -3.603 & 3.274 & & -1.100 & .281 \\
\hline & Kompetensi & 1.204 & .183 & .872 & 6.597 & .000 \\
\hline & LingkunganKerja & .063 & .153 & .054 & .409 & .686 \\
\hline
\end{tabular}

Berdasarkan data hasil analisis regresi berganda yang ditunjukkan oleh tabel 9 diatas maka dapat disusun persamaan regresinya sebagai berikut:

\section{$Y:-3,603+1,204 X 1+0,063 X 2+e$}

Persamaan regresi diatas memperlihatkan hubungan antara variabel independen dengan variabel dependen, dari persamaan tersebut dapat diambil kesimpulan:

1. Nilai koefisien regresi variabel kompetensi (X1) adalah 1,204 artinya jika variabel kompetensi (X1) berubah kearah lebih baik sebesar 1 skala dengan asumsi variabel lingkungan kerja (X2) dan konstanta adalah 0 (nol), maka cenderung meningkat 1,204 kali dari sebelumnya. Hal tersebut menunjukkan bahwa variabel gaya kompetensi berkontribusi positif terhadap kinerja karyawan PT. Bank Rakyat Indonesia (persero), Tbk Kantor Makassar.

2. Nilai koefisien regresi lingkungan kerja $(X 2)$ 0,063 artinya jika variabel lingkungan kerja $(X 2)$ lebih baik dengan asumsi variabel kompetensi (X1) dan konstanta adalah 0 (nol), maka kinerja karyawan pada PT. Bank Rakyat Indonesia (persero), Tbk kantor Makassar dengan meningkat 0,063 kali dari biasanya, hal tersebut menunjukkan bahwa variabel lingkungan kerja berkontribusi positif terhadap kinerja karyawan PT. Bank Rakyat Indonesia (persero), Tbk Kantor Makassar.

Uji F dilakukan dengan tujuan untuk mengetahui seberapa jauh variabel independen atau bebas secara bersama-sama dapat mempengaruhi variabel dependen atau terikat. Adapun hasil uji F dapat dilihat pada tabel 11 berikut ini :

Tabel 8. Uji F

\begin{tabular}{|c|c|c|c|c|c|c|}
\hline \multicolumn{7}{|c|}{ ANOVA $^{a}$} \\
\hline Model & & Sum of Squares & Df & Mean Square & $\mathbf{F}$ & Sig. \\
\hline \multirow{3}{*}{1} & Regression & 328.171 & 2 & 164.086 & 70.739 & $.000^{\mathrm{b}}$ \\
\hline & Residual & 62.629 & 27 & 2.320 & & \\
\hline & Total & 390.800 & 29 & & & \\
\hline \multicolumn{7}{|c|}{ a. Dependent Variable: KinerjaKaryawan } \\
\hline $\begin{array}{l}\text { b. Pred } \\
\text { Sumber }\end{array}$ & $\begin{array}{l}\text { tors: (Consta } \\
\text { Hasil Olahan }\end{array}$ & $\begin{array}{l}\text { LingkunganKerja, } \\
\text { SPSS 20,2021 }\end{array}$ & npetensi & & & \\
\hline
\end{tabular}


Berdasarkan uji F pada tabel 8 dapat diketahui nilai signifikansi untuk pengaruh X1 dan X2 secara simultan terhadap $\mathrm{Y}$ adalah sebesar $0,000<0,05$. Dan nilai $\mathrm{F}$ hitung 70,739 $>\mathrm{F}$ tabel 3,34 sehingga hasil ini memiliki arti bahwa variabel $\mathrm{X} 1$ dan $\mathrm{X} 2$ secara simultan mempunyai pengaruh terhadap variabel $\mathrm{Y}$. Uji koefisien determinasi dilakukan untuk menunjukkan sejauh mana tingkat hubungan antara variabel dependen dengan variabel independen, atau sejauh mana variabel mempengaruhi variabel dependen. Analisis koefisien determinasi (R2) digunakan untuk mengetahui seberapa besar persentase (\%) pengaruh keseluruhan variabel independen terhadap variabel dependen. Hasil uji dapat dilihat pada tabel 10 dibawah ini :

Tabel 9. Koefisien Determinasi (R2)

\begin{tabular}{|c|c|c|c|c|}
\hline \multicolumn{5}{|c|}{ Model Summary } \\
\hline Model & $\mathbf{R}$ & R Square & Adjusted R Square & $\begin{array}{l}\text { Std. Error of the } \\
\text { Estimate }\end{array}$ \\
\hline 1 & $.916^{\mathrm{a}}$ & .840 & .828 & 1.523 \\
\hline
\end{tabular}

Dari tabel 9, dapat diketahui : 1). Koefisien kolerasi (R) sebesar 0,916. Hal tersebut menunjukkan adanya hubungan yang kuat antara variabel independen dan variabel dependen (karena mendekati angka 1). 2) Koefisien determinasi (R2) sebesar 0,840, artinya bahwa kontribusi variabel independen mempengaruhi variabel dependen sebesar $84 \%$, sisanya $16 \%$ dijelaskan oleh variabel lain diluar model.

\subsection{Pembahasan}

Penelitian ini bertujuan untuk mengetahui pengaruh kompetensi (X1), lingkungan kerja (X2) terhadap kinerja karyawan (Y), PT. Bank Rakyat Indonesia (persero), Tbk kantor Makassar. Kompetensi adalah kemampuan seseorang yang dapat terobservasi mencakup atas pengetahuan, keterampilan dan sikap kerja dalam menyelesaikan suatu pekerjaan atau tugas sesuai dengan standar performa yang ditetapkan. Berdasarkan hasil uji hipotesis pengaruh kompetensi terhadap kinerja karyawan PT. Bank Rakyat Indonesia (persero), Tbk Kantor Makassar menghasilkan nilai signifikansi 0,000 $<0,05$ dan (thitung) sebesar 6,597 > 2,0518 (t-tabel), artinya kompetensi berpengaruh positif terhadap kinerja karyawan sehingga hipotesis 1 diterima. Lingkungan kerja adalah kehidupan sosial, psikologi dan fisik dalam perusahaan yang berpengaruh terhadap pekerja dalam melaksanakan tugasnya. Kehidupan manusia tidak terlepas dari berbagai keadaan lingkungan sekitarnya, antara manusia dan ligkungan terdapat hubungan yang sangat erat. Dalam hal ini, manusia akan selalu berusaha untuk beradaptasi dengan berbagai keadaan lingkungan sekitarnya. Demikian pula halnya ketika melakukan pekerjaan, karyawan sebagai manusia tidak dapat dipisahkan dari berbagai keadaan disekitar tempat bekerja, yaitu lingkungan kerja. Berdasarkan hasil uji hipotesis pengaruh lingkungan kerja terhadap kinerja karyawan PT. Bank Rakyat Indonesia (persero), Tbk Kantor Makassar menghasilkan nilai signifikansi 0,686 > 0,05 dan (t-hitung) sebesar 0,409 < 2,0518 (t-tabel), artinya lingkungan kerja berpengaruh signifikan terhadap kinerja karyawan, sehingga hipotesis 2 ditolak.

\section{Simpulan dan Saran}

Berdasarkan hasil analisis dan pembahasan yang telah dijelaskan di bab sebelumnya, dapat disimpulkan sebagai berikut:

1. Kompetensi berpengaruh positif dan signifikan terhadap kinerja karyawan PT. Bank Rakyat Indonesia (persero), Tbk Kantor Cabang Makassar

2. Berdasarkan analisis regresi berganda dapat diketahui bahwa lingkungan kerja berpengaruh positif terhadap kinerja karyawan, karena diperoleh nilai positif. Sedangkan berdasarkan uji $\mathrm{T}$ diperoleh kesimpulan bahwa variabel lingkungan kerja tidak berpengaruh signifikan terhadap kinerja karyawan PT. Bank Rakyat Indonesia (persero), Tbk Kantor Kab. Makassar. Pengaruh lingkungan kerja yang tidak signifikan terhadap kinerja karyawan bisa dikarenakan hubungan kerja sesama karyawan atau atasan yang kurang baik. 


\section{DAFTAR PUSTAKA}

Anjani, A. (2019). Pengaruh Kompetensi dan Motivasi Kerja Terhadap Kinerja Karyawan. Jurnal Inspirasi Bisnis Dan Manajemen, 3(1), 1. https:/ / doi.org/10.33603/jibm.v3i1.2191

Arianto, D. A. N. (2013). Pengaruh kedisiplinan, lingkungan kerja dan budaya kerja terhadap kinerja tenaga pengajar. Jurnal Economia, 9(2), 191-200.

Ashari, B. (2013). Pengaruh Partisipasi Penyusunan Anggaran Terhadap Kinerja Manajerial Dengan Budaya Organisasi Dan Struktur Organisasi Sebagai Variabel Moderating (Studi Empiris pada SKPD di Kabupaten Agam). Jurnal Akuntansi, 1(3).

Athar, H. S. (2020). Pengaruh Kepemimpinan, Kedisiplinan Dan Lingkungan Kerja Terhadap Kinerja Pegawai Kantor Kecamatan Selong Kabupaten Lombok Timur. Jurnal Riset Manajemen Dan Bisnis (JRMB) Fakultas Ekonomi UNIAT, 5(1), 57-64.

Basori, M. A. N., Prahyawan, W., \& Kamsin, D. (2017). Pengaruh Kompetensi Karyawan dan Lingkungan Kerja Terhadap Kinerja Karyawan Melalui Motivasi Kerja Sebagai Variabel Intervening (Studi Pada PT. Krakatau Bandar Samudera). Jurnal Riset Bisnis Dan Manajemen Tirtayasa, 1(2).

Berger, J. (2008). Identity signaling, social influence, and social contagion. Understanding Peer Influence in Children and Adolescents, 181-199.

Budhiningtias Winanti, M. (2011). Pengaruh Kompetensi Terhadap Kinerja Karyawan (Survei pada PT. Frisian Flag Indonesia Wilayah Jawa Barat). Majalah Ilmiah UNIKOM.

Burt, R. S. (1987). Social contagion and innovation: Cohesion versus structural equivalence. American Journal of Sociology, 92(6), 1287-1335.

Desplaces, D. (2005). A multilevel approach to individual readiness to change. Journal of Behavioral and Applied Management, 7(1), 25.

Fajrin, I. Q., \& Susilo, H. (2018). Pengaruh Gaya Kepemimpinan Terhadap Kinerja Karyawan Dengan Motivasi Kerja Sebagai Variabel Intervening (Studi pada Karyawan Pabrik Gula Kebon Agung Malang). Jurnal Administrasi Bisnis, 61(4), 117-124.

Fauzi, M. P. (2012). Pengaruh Upah Dan Lingkungan Kerja Terhadap Kinerja Karyawan Pada PT Coca-Cola Bottling Indonesia Central Java Ungaran Semarang. Universitas Muhammadiyah Surakarta.

Fitri, N., \& Nasution, A. P. (2016). Pengaruh Gaya Kepemimpinan, Penilaian Prestasi Kerja Dan Lingkungan Kerja Terhadap Kepuasan Kerja Karywan Pada Pt. Schneider Electric Manufacturing Batam. JURNAL BENING, 3(1).

Fredickson, B. L. (2001). The role of positive emotions in positive psychology. American Psychologist, 56(3), 218-226.

Fredrickson, B. L. (2004). The broaden-and-build theory of positive emotions. Philosophical Transactions of the Royal Society of London. Series B: Biological Sciences, 359(1449), 1367-1377.

Gibson, J. L., Ivancevich, J. M., \& Donelly, J. H. (1996). Perilaku Organisasi. Edisi Kedelapan, Jilid Satu, Binarupa Aksara, Jakarta.

Hanafi, B. D., \& Yohana, C. (2017a). Pengaruh motivasi, dan lingkungan kerja, terhadap kinerja karyawan, dengan kepuasan kerja sebagai variabel mediasi pada PT BNI Lifeinsurance. Jurnal Pendidikan Ekonomi Dan Bisnis (JPEB), 5(1), 73-89.

Hanafi, B. D., \& Yohana, C. (2017b). Pengaruh Motivasi, Dan Lingkungan Kerja, Terhadap Kinerja Karyawan, Dengan Kepuasan Kerja Sebagai Variabel Mediasi Pada Pt Bni Lifeinsurance. Jurnal Pendidikan Ekonomi Dan Bisnis (JPEB), 5(1), 73-89. https://doi.org/10.21009/jpeb.005.1.6

Hapsari, D. R. (2016). Peran Jaringan Komunikasi Dalam Gerakan Sosial Untuk Pelestarian Lingkungan Hidup. Jurnal Komunikasi Ikatan Sarjana Komunikasi Indonesia, 1(1), 25. https:// doi.org/10.25008/jkiski.v1i1.33

Hasibuan, S. M. (2018). Pengaruh Kepemimpinan, Lingkungan Kerja dan Motivasi Kerja terhadap Kinerja. Maneggio: Jurnal Ilmiah Magister Manajemen, 1(1), 71-80.

Hendriani, S., Efni, Y., \& Fitriani, A. (2013). Pengaruh pendidikan dan pelatihan, kompetensi terhadap kinerja karyawan PT. Bank Riau Kepri Kantor Pusat Pekanbaru. PEKBIS (Jurnal Pendidikan Ekonomi Dan Bisnis), 5(2), 133-144.

Hodge, B. J., Anthony, W. P., \& Gales, L. M. (1988). Organizational theory. Martin \& Shell, Management of Professionals: Insights for Maximising Cooperation, 3rd Edn, M Dekker, New York.

Hutapea, P., \& Nurianna Thoha, M. B. A. (2008). Kompetensi plus. Gramedia Pustaka Utama. 
Jones, G. R. (2001). Organizational theory: Text and cases. Prentice Hall.

Kasiram, R., \& Raj, A. C. (2011). Development and strengthening of aluminium alloy (Al-Cu) by mechanical working and heat treatment. Development, 2(4).

Kast, F. E., \& Rosenzweig, J. E. (1972). General systems theory: Applications for organization and management. Academy of Management Journal, 15(4), 447-465.

Kerja, P. D., Karir, P., Kompetensi, D. A. N., \& Tulung, J. E. (2018). Pengaruh Disiplin Kerja, Perencanaan Karir Dan Kompetensi Terhadap Kinerja Karyawan Kantor Pelayanan Pajak (Kpp) Pratama Manado. Jurnal EMBA: Jurnal Riset Ekonomi, Manajemen, Bisnis Dan Akuntansi, 6(1). https://doi.org/10.35794/emba.v6i1.19153

Khoiriyah, L. (2009). Pengaruh upah dan lingkungan kerja terhadap kinerja karyawan pada CV. Aji Bali Jayawijaya Surakarta. Universitas Muhammadiyah Surakarta.

Lestary, L., \& Chaniago, H. (2017). Pengaruh Lingkungan Kerja Terhadap Kinerja Karyawan. Jurnal Riset Bisnis Dan Investasi, 3(2), 94-103.

Locher, D. A. (2002). Social Contagion Theory. DA Lochner, Collective Behavior, 11-23.

Luthan, F. (2006). Perilaku Organisasi, edisi kesepuluh. Yogyakarta: Penerbit ANDI.

Mamesah, A. M. C., Kawet, L., \& Lengkong, V. P. K. (2016). Pengaruh Lingkungan Kerja, Disiplin Kerja, dan Loyalitas Kerja Terhadap Kinerja Karyawan Pada LPP RRI Manado. Jurnal EMBA: Jurnal Riset Ekonomi, Manajemen, Bisnis Dan Akuntansi, 4(3).

Markus, M. (2020). Pengaruh Kualitas Pelayanan Dan Fasilitas Terhadap Kepuasaan Pelanggan (Studi Kasus Pada Spbu Muara Siban Kecamatan Pulau Pinang Kabupaten Lahat. MOTIVASI: Jurnal Manajemen Dan Bisnis, 5(2), 885-891.

Moorhead, G., \& Griffin, R. W. (2013). Perilaku Organisasi: Manajemen Sumber Daya Manusia dan Organisasi. Jakarta: Salemba Empat.

Muntu, G. F. B., Tumbuan, W. J. F. A., \& Ogi, I. W. J. (2020). the Effect of Work Experience and Competence on Employee Performance At Pt . Pln ( Persero ) Sulutenggo Region. 8(1), 459-468.

Ningsih, V., Sari, R. N., \& Rasuli, M. (2018). Analisis Penerapan E-Planning Dan E-Budgeting Pada Pemerintah Daerah (Studi Kasus Pada Pemerintah Kabupaten Bengkalis). Jurnal Ekonomi, 26(2), $18-31$.

Paliema, D., Mandey, J., \& Ogotan, M. (2016). Pengaruh Struktur Organisasi Terhadap Kualitas Pelayanan Publik (Suatu Studi Di Dinas Kependudukan dan Pencatatan Sipil Kabupaten Halmahera Utara). Jurnal Administrasi Publik, 1(37).

Paradizsa, I., Malik, L. I., Isa, M., \& Anugrah, P. (2019). Self-Esteem, Contagion Theory dan Suporter Persija Jakarta. Jurnal Komunikasi, 11(1), 1. https:// doi.org/10.24912/jk.v10i1.2072

Prahiawan, W., \& Simbolon, N. (2014). Pengaruh Motivasi Intrinsik dan Lingkungan Kerja terhadap Kinerja Karyawan pada PT Intimas Lestari Nusantara. Jurnal Ekonomi Universitas Esa Unggul, 5(1), 17914.

Pratiwi, D. E. (2019). Analisis Ketersediaan Sarana dan Prasarana Terhadap Motivasi Belajar Siswa SD pada Zona Utara Kabupaten Mojokerto. ELSE (Elementary School Education Journal): Jurnal Pendidikan Dan Pembelajaran Sekolah Dasar, 3(1), 55-65.

Rafferty, A. E., \& Griffin, M. A. (2009). Job satisfaction in organizational research. The Sage Handbook of Organizational Research Methods, 196-212.

Robbins, D. L., \& Galperin, B. L. (2010). Constructive deviance: striving toward organizational change in healthcare. Journal of Management and Marketing Research, 5, 1.

Saputra, I. P. A., Bagia, I. W., \& Suwendra, I. W. (2016). Pengaruh Kompetensi Dan Disiplin Kerja Terhadap Kinerja Karyawan. Jurnal Manajemen Indonesia, 4(1).

Scott, W. R. (1995). Symbols and organizations: from Barnard to the institutionalists. Organization Theory: From Chester Barnard to the Present and beyond, 38-55.

Setyawan, E., \& UST, A. F. E. (2018). Persepsi Produk Coffee Shop Cuppajo Dan Repurchase Intention Di YOGYAKARTA. Jurnal Ekobis Dewantara Vol, 1(8).

Somantrie, H. (2010). "Kompetensi" Sebagai Landasan Konseptual Kebijakan Kurikulum Sekolah di Indonesia. Jurnal Pendidikan Dan Kebudayaan, 16(6), 684-698.

Sudarmiani, C. Y. P. (2018). Pengaruh Kepuasan Kerja Terhadap Turnover Intention Pada CV Surya Nedika Isabella. EQUILIBRIUM: Jurnal Ilmiah Ekonomi Dan Pembelajarannya, 6(2), 176-186.

Sukmawati, F. (2007). Pengaruh Kepemimpinan, Lingkungan Kerja Fisik, dan Kompensasi terhadap Kinerja Karya di PT. Pertamina (Persero) Upms III Terminal Transit Utama Balongan, Indramayu. STIE YKPN. 
Sutrisno, H. E. (2008). Pengaruh Pengembangan SDM dan Kepribadian Terhadap Kompetensi dan Prestasi Kerja Karyawan Pada PT. Barata Indonesia di Gresik. EKUITAS (Jurnal Ekonomi Dan Keuangan), 12(4), 455-473.

Tugade, M. M., Fredrickson, B. L., \& Feldman Barrett, L. (2004). Psychological resilience and positive emotional granularity: Examining the benefits of positive emotions on coping and health. Journal of Personality, 72(6), 1161-1190.

Tyagi, S., Choudhary, A., Cai, X., \& Yang, K. (2015). Value stream mapping to reduce the lead-time of a product development process. International Journal of Production Economics, 160, 202-212.

Wahyuadianto, A. (2010). Komitmen Pns Terhadap Organisasi Di Rektorat Universitas Negeri Yogyakarta. Widyariset, 13(1), 1-10.

Wibowo, C. T. (2015). Analisis pengaruh kecerdasan emosional (EQ) dan kecerdasan spiritual (SQ) pada kinerja karyawan. Jurnal Bisnis Dan Manajemen (Journal of Business and Management), 15(1), 1-16.

Wibowo, N. (2016). Upaya memperkecil kesenjangan kompetensi lulusan sekolah menengah kejuruan dengan tuntutan dunia industri. Jurnal Pendidikan Teknologi Dan Kejuruan, 23(1), 45-59.

Wijono, S. (2010). Psikologi industri \& organisasi. Kencana.

Yeni, F. (2016). Hubungan Emosi Positif dengan Kepuasan Hidup Pada Lanjut Usia (LANSIA) di Kota Padang Provinsi Sumatera Barat. NERS Jurnal Keperawatan, 9(1), 7-12. 